\title{
Obturacyjny bezdech senny - diagnostyka i postępowanie terapeutyczne
}

\section{Obstructive sleep apnea - diagnosis and treatment options}

\author{
Donat Domaradzki ${ }^{1}$, Piotr J. Stryjewski ${ }^{2}$, Małgorzata Konieczyńska ${ }^{1}$, Jacek Lelakowski ${ }^{3}$ \\ ${ }^{1}$ Oddział Szybkiej Diagnostyki Krakowskiego Szpitala Specjalistycznego im. Jana Pawła II w Krakowie \\ ${ }^{2}$ Oddział Kardiologii Szpitala Powiatowego w Chrzanowie \\ ${ }^{3}$ Oddział Kliniczny Elektrokardiologii Krakowskiego Szpitala Specjalistycznego im. Jana Pawła II w Krakowie, Instytut Kardiologii, \\ Collegium Medicum Uniwersytetu Jagiellońskiego w Krakowie
}

\section{Streszczenie}

Obturacyjny bezdech senny (OSA) jest schorzeniem polegającym na powtarzających się epizodach bezdechów i spłyceń oddechu spowodowanych całkowitą bądź częściową blokadą przepływu powietrza. Głównymi objawami OSA są: nadmierna senność w ciągu dnia, nagłe wybudzenia z uczuciem zatrzymania oddechu lub duszenia się, suchość w jamie ustnej po przebudzeniu, poranne bóle głowy, trudności w koncentracji, potliwość nocna i inne. Częstość występowania OSA jest wysoka i prawdopodobnie, z powodu zwiększającej się częstości otyłości, będzie większa w przyszłości. W wielu badaniach wykazano korelacje między OSA a innymi schorzeniami, takimi jak: nadciśnienie tętnicze, przewlekła niewydolność krążenia, choroba niedokrwienna serca, arytmie, udar mózgu. Istnieje również wiele publikacji wskazujących na korzystny wpływ terapii z użyciem stałego dodatniego ciśnienia w drogach oddechowych (CPAP) na schorzenia współistniejące. „Złotym standardem” w diagnostyce OSA jest tak zwana stacjonarna polisomnografia (PSG), ale urządzenia przenośne typu 3 (z min. 4 kanałami) również są akceptowalne w diagnostyce pacjentów wyjściowo obciążonych umiarkowanym lub wysokim ryzykiem OSA. Diagnozę stawia się na podstawie wyników PSG i objawów. Na podstawie wyniku PSG można podzielić OSA na 3 grupy - łagodne, umiarkowane i ciężkie. Według aktualnych wytycznych i publikacji CPAP jest leczeniem pierwszego wyboru w umiarkowanej i ciężkiej postaci OSA. Strategia lecznicza w przypadku bezdechu łagodnego zależy od zdrowia pacjenta, schorzeń współistniejących i indywidualnych decyzji chorego. Innymi opcjami leczenia są aparaty wewnątrzustne, leczenie pozycyjne i chirurgiczne, ale żadna z tych metod nie dorównuje korzyściom wynikającym z terapii CPAP.

Słowa kluczowe: bezdech, obturacyjny bezdech senny, OSA, CPAP, chrapanie, nadmierna senność, ospałość

Folia Cardiologica 2016; 11, 3: 253-259

\section{Wstęp}

Obturacyjny bezdech senny (OSA, obstructive sleep apnea) należy do grupy zaburzeń oddychania w czasie snu (SDB, sleep disordered breathing), obok centralnego bezdechu sennego, zespołów hipowentylacji i innych rzadszych schorzeń. Podstawowym mechanizmem prowadzącym do OSA jest nadmierny spadek napięcia mięśni odpowiedzialnych za utrzymanie drożności górnych dróg oddechowych, co prowadzi do powtarzających się epizodów bezdechów (apnea) lub spłyceń oddechu (hypopnea), spowodowanych odpowiednio - przez całkowite zablokowanie lub znaczne ograniczenie przeływu powietrza na poziomie gardła, mimo zachowanego wysiłku oddechowego [1]. Zdarzenia te prowadzą to powtarzających się epizodów hipoksji, hiperkapnii, zwiększonych wahań ciśnień wewnątrz klatki piersiowej

Adres do korespondencji: lek. Donat Domaradzki, Oddział Szybkiej Diagnostyki, Krakowski Szpital Specjalistyczny im. Jana Pawła II, ul. Prądnicka 80, 31-202 Kraków, e-mail: donat.domaradzki@gmail.com 


\begin{tabular}{|c|c|c|c|c|}
\hline \multicolumn{5}{|c|}{$\begin{array}{l}\text { Z jakim prawdopodobieństwem zasnąłlbyś/zasnęłabyś w następujących sytuacjach: } \\
0 \text { - nie zasnę nigdy } \\
1 \text { - małe prawdopodobieństwo zaśnięcia } \\
2 \text { - prawdopodobnie zasnę } \\
3 \text { - na pewno zasnę }\end{array}$} \\
\hline & 0 & 1 & 2 & 3 \\
\hline \multicolumn{5}{|l|}{ Siedzenie lub czytanie } \\
\hline \multicolumn{5}{|l|}{ Oglądanie telewizji } \\
\hline \multicolumn{5}{|l|}{ Bierne siedzenie w miejscu publicznym (poczekalnia, kino) } \\
\hline \multicolumn{5}{|l|}{ Podczas godzinnej jazdy samochodem jako pasażer } \\
\hline \multicolumn{5}{|l|}{ Po południu, leżąc } \\
\hline \multicolumn{5}{|l|}{ Podczas rozmowy, siedząc } \\
\hline \multicolumn{5}{|l|}{ Po obiedzie, leżąc } \\
\hline Prowadząc samochód, podczas oczekiwania na światłach, w korku & & & & \\
\hline
\end{tabular}

Rycina 1. Skala Senności Epworth (ESS, Epworth Sleepiness Scale) (opracowano na podstawie: Johns M.W. Sleep 1991; 14: 540-545)

i zwiększonej aktywności układu sympatycznego [2]. Obturacyjny bezdech senny stanowi problem interdyscyplinarny, jako że w wielu badaniach udowodniono związek między OSA a innymi schorzeniami. Ponadto autorzy coraz większej liczby badań dowodzą, że u osób z OSA ryzyko wypadków samochodowych jest wyższe niż u osób zdrowych [3, 4], a odpowiednie leczenie za pomocą stałego dodatniego ciśnienia w drogach oddechowych (CPAP, continuous positive airway pressure) może zarówno zmniejszyć liczbę tych zdarzeń oraz liczbe zgonów, jak i znacznie ograniczyć koszty ponoszone przez ochronę zdrowia [5-7]. Od 31 grudnia 2015 roku, na terenie Unii Europejskiej, obowiazuje nowa dyrektywa dotycząca kierowców z rozpoznanym OSA, jak również podejrzanych jego występowanie. Zaleca się diagnostykę w kierunku OSA u wszystkich aplikujących bądź przedłużających prawo jazdy, u których podejrzewa się umiarkowaną lub ciężką postać OSA, a także okresową kontrolę terapii u pacjentów ze zdiagnozowanym schorzeniem [8]. Częstość występowania OSA, określana w różnych populacjach, waha się od $2 \%$ do ponad $10 \%$ $[1,9,10]$. W Polsce jego częstość szacuje się na 11,2\% u mężczyzn i 3,4\% kobiet [1]. W stosunkowo niedawno opublikowanym badaniu HypnoLaus, w którym przeprowadzono analizę wyników badań polisomnograficznych (PSG, polysomnography) wykonanych w grupie 2121 pacjentów, OSA o stopniu umiarkowanym lub ciężkim stwierdzono u 23,4\% kobiet i 49,7\% mężczyzn [11]. Tak wysoką częstość autorzy tłumaczą nowszymi i dużo dokładniejszymi metodami diagnostyki i analizy.

\section{Czynniki ryzyka i objawy OSA}

Wśród czynników ryzyka w pierwszej kolejności należy wymienić otyłość, następnie płeć męską, obwód szyi powyżej
$43 \mathrm{~cm}$ u mężczyzn i $40 \mathrm{~cm}$ u kobiet oraz wiek (u mężczyzn > 40. rż., u kobiet > 50. rż.). Inne czynniki ryzyka to: zmiany $w$ budowie górnych dróg oddechowych powodujące zaburzenie ich drożności (np. przerost migdałków podniebiennych, podniebienia miękkiego, języczka, skrzywienie przegrody nosowej), retrognacja, spożywanie alkoholu przed snem, stosowanie leków nasennych lub miorelaksacyjnych, nikotynizm [1, 2, 12-17].

Objawy OSA można podzielić na nocne i dzienne; do nocnych zalicza się chrapanie, zauważone epizody bezdechów, wybudzenia z uczuciem duszenia się lub braku tchu, nykturię, nadmierną potliwość (głównie w zakresie górnej połowy ciała), przerywany sen, problemy z zaśnięciem z powodu lęku, natomiast do występujących w dzień: nadmierną senność w ciągu dnia (ocenianą najczęściej przy użyciu Skali Senności Epworth [ESS, Epworth Sleepiness Scale], ryc. 1), sen nieprzynoszący odpoczynku, suchość w jamie ustnej po przebudzeniu, poranne bóle głowy, trudności z koncentracją i pamięcią, zaburzenia libido, impotencje [1, 17-19]. W przesiewowej ocenie pacjentów przydatny może być również kwestionariusz STOP - BANG, którego schemat przedstawiono na rycinie 2 .

\section{Diagnostyka}

Rozpoznania OSA dokonuje się na podstawie PSG oraz objawów klinicznych. Choć obecnie obowiązującym „złotym standardem" w postępowaniu diagnostycznym u pacjentów podejrzanych o występowanie OSA jest wykonanie PSG, to w wielu badaniach dowiedziono, że urządzenia przenośne (PM, portable monitoring) są równie wartościowymi narzędziami diagnostycznymi, a ze względu na niższe koszty i znacznie łatwiejszą konstrukcje - znacznie łatwiej dostępnymi [20, 21]. Diagnostyki OSA za pomoca 


\begin{tabular}{|c|c|}
\hline Snoring (chrapanie) & $\mathrm{BMI}>35 \mathrm{~kg} / \mathrm{m}^{2}$ \\
\hline Tiredness (zmęczenie) & Age (wiek) > 50 lat \\
\hline Observed apneas (zauważone epizody bezdechów) & Neck (obwód szyi) $>40 \mathrm{~cm}$ \\
\hline Blood Pressure - Hypertension (nadciśnienie tętnicze) & Gender (płeć) - męska \\
\hline \multicolumn{2}{|c|}{$\begin{aligned} & \text { TAK }=1 \\
& \text { NIE }=0 \\
& \text { ię ze zwiększonym ryzykiem OSA }\end{aligned}$} \\
\hline
\end{tabular}

Rycina 2. Kwestionariusz STOP - BANG; BMI (body mass index) - wskaźnik masy ciała; OSA (obstructive sleep apnea) - obturacyjny bezdech senny (opracowano na podstawie: Chung F. i wsp. Anesthesiology 2008; 108: 812-821)

PM nie powinno się przeprowadzać u pacjentów z istotnymi chorobami współistniejącymi, na przykład umiarkowana/ /ciężką przewlekłą chorobą płuc, niewydolnością krążenia, chorobami nerwowo-mięśniowymi, bezsennością, parasomniami, zespołem niespokojnych nóg, zaburzenia rytmu dobowego, narkolepsją i innymi. Urządzenia przenośne nie służą również do badań przesiewowych w kierunku OSA ani nie powinno się ich wykorzystywać do badań u pacjentów bez objawów. Za pomocą PM powinno się monitorować przynajmniej trzy funkcje - przepływ powietrza (optymalnie przy użyciu kaniuli nosowej i termistora), wysiłek oddechowy i utlenowanie krwi. Większość PM spełniających te kryteria ma również czujnik pozycji ciała i/lub częstości akcji serca. Podczas badania PSG dodatkowo można korzystać z elektroencefalografii (EEG, electroencephalography), elektrookulografii (EOG, electrooculography), elektromiografii (EMG, electromyography) - typowo podbródkowo i obustronnie na piszczeli, elektrokardiografii (ECG, electrocardiograhpy). U pacjentów cechujących się wysokim prawdopodobieństwem występowani OSA w przypadku negatywnego wyniku na podstawie PM w celu weryfikacji należy wykonać PSG [22].

Wynik badania PSG/PM jest przedstawiany jako liczba incydentów oddechowych w trakcie godziny (h, hour). Niekiedy wynik badania wyraża się jako wartość wskaźnika bezdechów i spłyconych oddechów (AHI, apnea hypopnea index) lub wskaźnik wybudzeń związanych z wysiłkem oddechowym $(\mathrm{RDI}=\mathrm{AHI}+\mathrm{RERA}$ [respiratory effort related arousals]).

Rozpoznania można dokonać na podstawie wyniku PSG w przypadku, gdy RDI wynosi powyżej 15/h lub ponad 5/h przy współistniejącym przynajmniej jednym z następujących objawów: zasypianie w ciągu aktywności wbrew woli, zmęczenie, bezsenność, wybudzenia z uczuciem braku tchu, dławienia się, duszenia, zauważone przez otoczenie epizody przerw w oddychaniu, głośnego chrapania [2]. Zależnie od wyniku wyróżnia się trzy stopnie ciężkości OSA (tab. 1).

\section{Obturacyjny bezdech senny a inne schorzenia}

Jak wspomniano na wstępie, ze względu na liczne powiązania z innymi jednostkami chorobowymi OSA należy
Tabela 1. Trzy stopnie ciężkości obturacyjnego bezdechu sennego (OSA, obstructive sleep apnea)

$\begin{array}{lc}\text { Postać OSA } & \text { RDI }[\mathrm{n} / \mathrm{h}] \\ \text { Łagodna } & \geq 5 \mathrm{i}<15 \\ \text { Umiarkowana } & \geq 15 \mathrm{i} \leq 30 \\ \text { Ciężka } & >30\end{array}$

RDI (respiratory disturbance index) - liczba (n) bezdechów, spłyceń i wybudzeń w trakcie godziny [h] snu

traktować jako problem inderdyscyplinarny. Opisuje się ewidentny związek między występowaniem OSA a zwiększonym ryzykiem schorzeń i zgonów z powodu chorób układu sercowo-naczyniowego [23, 24].

0 związku między OSA a nadciśnieniem tętniczym (AH, artery hyperttension) jest mowa w piśmiennictwie od kilkudziesięcu lat. Ciekawe badanie prospektywne w dużej grupie 1889 pacjentów diagnozowanych w kierunku OSA, wyjściowo bez nadciśnienia tętniczego, przeprowadzono w latach 1994-2000 w Hiszpanii [25]. Wykazano że pacjenci z OSA w obserwacji prospektywnej istotnie częściej zapadali na AH niż osoby zdrowe. Ponadto w ostatnich latach OSA jest uzawany za najczęstszą przyczynę nadciśnienia opornego oraz jedną z głównych przyczyn nadciśnienia wtórnego [26, 27].

Udowodniono zwiększone ryzyko arytmii, szczególnie migotania przedsionków (AF, atrial fibrillation) u pacjentów z OSA [28, 29] - tym większe, im cięższa jesteś postać schorzenia [30]. Pacjenci z OSA częściej chorują na chorobę niedokrwienną serca (IHD, ischemic heart disease), a pacjenci z IHD częściej niż osoby zdrowe, chorują na OSA [31-33]. Również w grupie pacjentów z przewlekła niewydolnością serca (CHF, chronic heart failure) występowanie OSA jest istotnie większe niż w grupie zdrowych badanych [34], a współistnienie CHF i OSA zwiększa ryzyko złośliwych arytmii komorowych [35].

W opublikowanym w 2005 roku badaniu Yaggi i wsp. [36] wykazali, że OSA istotnie zwiększa ryzyko udaru mózgu. Badając pacjentów po przebytym udarze mózgu, stwierdzono, że występowanie OSA w tej grupie wiąże się ze zwiększonym ryzykiem wczesnego zgonu [37]. Ponadto jest dostępnych wiele badań sugerujących związek OSA z nie- 
prawidłowym metabolizmem glukozy. Z większości badań wynika, że u pacjentów z OSA glikemia na czczo jest wyższa, a metabolizm glukozy - gorszy niż u osób zdrowych [38].

\section{Leczenie}

Edukacja pacjenta jest podstawą leczenia każdego schorzenia. W przypadku OSA powinna obejmować omówienie patofijologii, czynników ryzyka, konsekwencji klinicznych OSA oraz sposobów terapii. Pacjent powinien być poinformowany o korzystnym wpływie zmniejszenia masy ciała i konieczności unikania poddających się modyfikacji czynników ryzyka (np. alkoholu, nikotynizmu) [2]. Ponadto nowe badania wskazują, że działania edukacyjne - zarówno behawioralne, jak i wspomagające pacjenta - wiążą się z lepszym compliance stosowania terapii CPAP [39].

Leczniem pierwszego wyboru w przypadku umiarkowanej i ciężkiej postaci OSA oraz w postaci łagodnej z objawami lub/i schorzeniami współistniejącymi jest terapia CPAP [2, 40, 41]. Celem stosowania dodatniego ciśnienia w drogach oddechowych (PAP, positive airway pressure) jest utrzymanie drożności w górnych drogach oddechowych, co zabezpiecza przed incydentami spłyceń oddechu i bezdechów. Przez lata nastąpił rozwój aparatury i obecnie są dostępne różne typy aparatów. Najczęściej stosowanym jest właśnie urządzenie utrzymujące stałe dodatnie ciśnienie na jednym poziomie (tj. CPAP). Kolejną funkcją, z której można skorzystać, jest tak zwana ulga wydechowa - opcja pozwalająca na obniżenie ciśnienia w trakcie wydechu pacjenta. Tak zwane aparaty automatyczne (APAP, autotitrating PAP) pozwalają na ustalenie zakresu ciśnień, w którym aparat samoczynnie, zależnie od detekcji oporu w drogach oddechowych i zdarzeń oddechowych, reguluje stosowane ciśnienie w założonym wcześniej zakresie. Nie należy stosować tej formy terapii u pacjentów z CHF, przewlekłą obturacyjną chorobą płuc, bezdechem centralnym i zespołami hipowentylacji [42]. „Dwupoziomowy” PAP (BPAP, bilevel PAP) polega na ustaleniu innego ciśnienia na czas wdechu oraz innego na czas wydechu pacjenta. Zarówno APAP, jak i BPAP to rzadziej stosowane rozwiązanie, w bardziej skomplikowanych przypadkach, a cena każdego z nich jest wyższa niż aparatów CPAP.

Terapia CPAP to nie tylko korzystny wpływ na objawy bezdechu i redukcję liczby zdarzeń oddechowych [43, 44], ale również korzystny wpływ na schorzenia współistniejące. We wspomnianym wcześniej badaniu [25], w którym oceniano pacjentów pod kątem korelacji OSA i AH, udowodniono, że stosowanie terapii CPAP obniża ryzyko wystąpienia $\mathrm{AH}$ w porównaniu z pacjentami z rozpoznanym OSA z różnych powodów niestosujących tej terapii. Istnieją jednak również badania, których wyniki nie są tak jednoznaczne [45, 46], a efekty pod postacią spadku ciśnienia tętniczego obserwowano tylko w niektórych podgrupach pacjentów. Podobne obserwacje wskazujące, że korzystny wpływ terapii CPAP jest widoczny tylko w niektórych podgrupach, poczyniono w metaanalizie, biorąc pod uwage jedynie randomizowane badania z grupą kontrolną [47]. Wydaje się, że grupami, które mogą odnieść największe korzyści, są pacjenci z wtórnym oraz źle kontrolowanym, opornym nadciśnieniem $[27,47,48]$.

Terapia CPAP wpływa korzystnie na objawy i częstość hospitalizacji pacjentów ze współistniejącymi OSA i AF [49], jak również obniża ryzyko nawrotu AF u pacjentów po kardiowersji [50, 51]. Z kolei leczenie OSA za pomocą CPAP u pacjentów z CHF poprawia ciśnienie tętnicze, funkcję skurczową lewej komory i zmniejsza średnią akcję serca [52]. Ponadto wykazano, że stosowanie terapii CPAP z dobrym compliance w tej grupie pacjentów obniża ryzyko zgonu i hospitalizacji [53], jak również ryzyko złośliwych arytmii [54].

Z wielu badań wynika, że terapia za pomocą CPAP może korzystnie wpływać na metabolizm glukozy $[55,56]$, jednak w celu wyciągnięcia jednoznacznych wniosków konieczne są dalsze badania.

\section{Pozostałe metody terapeutyczne}

Aparaty wewnątrzustne (OA, oral appliances) stosuje się najczęściej u pacjentów nadmiernie chrapiących bez OSA oraz u pacjentów z rozpoznanym OSA w stopniu łagodynym i ciężkim, którzy z różnych względów nie są w stanie/nie mogą stosować terapii CPAP. Optymalnym rozwiązaniem jest indywidualnie dobrany, regulowany aparat zastosowany w wyniku współpracy lekarza z doświadczonym stomatologiem [57, 58]. Wyróżnia się dwa typy aparatów [1, 59]:

- aparaty wysuwające żuchwę (różnie nazywane, np.: mandibular repositionig appliance [MRA], mandibular advancement device [MAD], mandibular repositioning device [MRD], mandibular advancement splint [MAS], mandibular advancement appliance [MAA]);

- aparaty pociągające język (TRD, tongue retaining device).

Odpowiednio dobrany, regulowany aparat umożliwia skuteczne zmniejszenia nasilenia OSA [60-62], należy jednak regularnie kontrolować pacjentów, ponieważ - jak wskazują niektóre badania w dłuższych obserwacjach może dojść do ponownego nasilenia choroby [63]. Przeciwwskazaniami do stosowania MRA są: bezdech centralny, stany chorobowe stawu skroniowo-żuchwowego, ciężkie choroby przyzębia, znaczne ubytki w uzębieniu, konieczność uzyskania szybkiej poprawy z powodu stanu pacjenta bądź charakteru chorób współistniejących. Działania niepożądane, na które najczęściej skarżą się pacjenci, to nadmierne ślinienie oraz - rzadziej - wysychanie jamy ustnej, reakcja odczynowa, dyskomfort żuchwy i otarcia zębów [64]. 
W postępowaniu chirurgicznym w leczeniu OSA można wyróżnić zabiegi bariatryczne oraz zabiegi korekcyjne w zakresie górnych dróg oddechowych. Najczęściej wykonywanymi zabiegami w zakresie górnych dróg oddechowych są uwulopalatofaryngoplastyka (UPPP, uvulopalatopharyngoplasty), tonsylektomia, septoplastyka. U dzieci najczęściej wykonuje się tonsylektomię i adenoidektomię. Zabiegi bariatryczne, wpływając na redukcję masy ciała, korzystnie oddziałują na zmniejszenie nasilenia OSA [65].

Leczenie pozycyjne stosuje się u pacjentów, u których większość lub wszystkie epizody oddechowe są związane z określoną pozycją ciała, co pozwala na rozpoznanie pozycyjnego OSA. Udowodniono również, że w takich przypadkach odpowiednio prowadzone leczenie pozycyjne może być skuteczne, ale trzeba pamiętać, że korzyści są mniejsze niż uzyskane za pomocą terapii CPAP $[66,67]$.

\section{Podsumowanie}

Jak wykazano powyżej, OSA stanowi istotny problem zdrowotny, jak również społeczny. Aktualne dane epidemiologiczne, choć bardzo rozbieżne, wskazują, że znaczna część populacji jest dotknięta OSA, a - zważywszy na dane prognostyczne o wzroście odsetka osób z nadwaga i otyłością - można się spodziewać stopniowego wzrostu liczby pacjentów z OSA. Objawy OSA, w tym głównie nadmierna senność dzienna, mogą prowadzić do poważnych zagrożeń zdrowotnych. Schorzenie to, ze względu na jego związki z wieloma innymi jednostkami chorobowymi, staje się problemem interdyscyplinarnym. Poza specjalistami pulmonologii lekarze wielu innych dziedzin powinni być zaznajomieni z problematyką bezdechu sennego. Obecnie kardiolodzy wydają się najbardziej „zainteresowaną” grupą lekarzy spośród innych specjalności, najpewniej w odpowiedzi na wzrastającą liczbę badań łączących OSA z chorobami układu sercowo-naczyniowego, co chociażby w przypadku AF, nadciśnienia opornego i wtórnego znalazło swoje odbicie również w aktualnych wytycznych wielu towarzystw kardiologicznych. Zauważalny jest również wzrost świadomości lekarzy podstawowej opieki zdrowotnej, co należy odebrać jako szczególnie korzystne, ponieważ właśnie ci lekarze najczęściej mają kontakt z pacjentem.

Wiadomo, że tylko część osób z tym schorzeniem przechodzi diagnostykę i zostają u nich wdrożone odpowiednie formy terapii. Wzrost świadomości społeczeństwa, wzrost świadomości lekarzy wielu specjalności, wzrost dostępności bezpłatnych badań w kierunku OSA powinny być głównymi celami w dążeniu do efektywniejszej, wcześniejszej diagnostyki i odpowiedniego leczenia.

\section{Konflikt interesów}

Autorzy deklarują brak konfliktu interesów.

\section{Abstract}

Obstructive sleep apnea (OSA) is a disease characterized by recurrent episodes of apneas and hypopneas, caused by total or partial airway obstruction. Main symptoms of OSA are: excessive daytime sleepiness, snoring, waking up suddenly feeling like gasping or choking, dry mouth or sore throat after waking up, morning headaches, trouble concentrating, night sweats and others. Prevalence of OSA is high and probably - due to increasing prevalence of obesity - will be higher in the future. Many studies show correlation between OSA and other diseases such as hypertension, chronic heart failure, coronary artery disease, arrhythmias and stroke. There are also many publications showing positive impact of CPAP treatment on managing comorbidities. Gold standard in diagnosis of OSA is in-laboratory polysomnography (PSG), although type 3 portable monitors (with at least 4 channels) are also acceptable to diagnose patients with pre-test moderate to high risk of OSA. Diagnosis is made based on PSG results and symptoms. Based on PSG results, we can divide OSA into 3 groups: mild, moderate and severe. Based on current guidelines and publications, continuous positive airway pressure (CPAP) is a first choice treatment in moderate and severe OSA. Treatment strategies in mild OSA depend on patient health, comorbidities and individual patient decisions. Other treatment options are oral appliances, positional treatment and surgery but none of them equals CPAP's benefits.

Key words: apnea, obstructive sleep apnea, OSA, CPAP, snoring, excessive sleepiness, somnolence

Folia Cardiologica 2016; 11, 3: 253-259 


\section{Piśmiennictwo}

1. Szczeklik A., Gajewski P. Interna Szczeklika. Podręcznik chorób wewnętrznych 2015. Medycyna Praktyczna, Krakow 2015.

2. Epstein L.J., Kristo D., Strollo P.J. i wsp. Clinical guideline for the evaluation, management and long-term care of obstructive sleep apnea in adults. J. Clin. Sleep Med. 2009; 5: 263-276.

3. Ellen R.L., Marshall S.C., Palayew M. i wsp. Systematic review of motor vehicle crash risk in persons with sleep apnea. J. Clin. Sleep Med. 2006; 2: 193-200.

4. Mulgrew A.T., Nasvadi G., Butt A. i wsp. Risk and severity of motor vehicle crashes in patients with obstructive sleep apnoea/hypopnoea. Thorax 2008; 63: 536-541.

5. Sassani A., Findley L.J., Kryger M. i wsp. Reducing motor-vehicle collisions, costs, and fatalities by treating obstructive sleep apnea syndrome. Sleep 2004; 27: 453-458.

6. George C.F. Reduction in motor vehicle collisions following treatment of sleep apnoea with nasal CPAP. Thorax 2001; 56: 508-512.

7. Tregear S., Reston J., Schoelles K., Phillips B. Continuous positive airway pressure reduces risk of motor vehicle crash among drivers with obstructive sleep apnea: systematic review and meta-analysis. Sleep 2010; 33: 1373-1380.

8. Bonsignore M.R., Randerath W., Riha R. i wsp. New rules on driver licensing for patients with obstructive sleep apnea: European Union Directive 2014/85/EU. J. Sleep Res. 2016; 25: 3-4.

9. Sharma S.K., Katoch V.M., Mohan A. i wsp. Consensus and evidence-based Indian initiative on obstructive sleep apnea guidelines 2014 (first edition). Lung India 2015; 32: 422-434.

10. Bixler E.O., Vgontzas A.N., Lin H.M. i wsp. Prevalence of sleep-disordered breathing in women: effects of gender. Am. J. Respir. Crit. Care Med. 2001; 163 (3 Pt 1): 608-613.

11. Heinzer R., Vat S., Marques-Vidal P. i wsp. Prevalence of sleep-disordered breathing in the general population: the HypnoLaus study. Lance Respir. Med. 2015; 3: 310-318.

12. Jordan A.S., McSharry D.G., Malhotra A. Adult obstructive sleep apnoea. Lancet 2014; 383: 736-747.

13. Garvey J.F., Pengo M.F., Drakatos P., Kent B.D. Epidemiologica aspects of obstructive sleep apnea. J. Thorac. Dis. 2015; 7: 920-929.

14. Issa F.G., Sullivan C.E. Alcohol, snoring and sleep apnea. J. Neurol. Neurosurg. Psychiatry 1982; 45: 353-359.

15. Wetter D.W., Young T.B., Bidwell T.R. i wsp. Smoking as a risk factor for sleep-disordered breathing. Arch. Intern. Med. 1994; 154 2219-2224.

16. Reed K., Pengo M.F., Steier J. Screening for sleep-disordered breathing in a bariatric population. J. Thorac. Dis. 2016; 8: 268-275.

17. Tishler P.V., Larkin E.K., Schluchter M.D., Redline S. Incidence of sleep-disordered breathing in an urban adult population: the relative importance of risk factors in the development of sleep-disordered breathing. JAMA 2003; 289: 2230-2237.

18. Mannarino M.R., Di Filippo F., Pirro M. Obstructive sleep apnea syndrome. Eur. J. Intern. Med. 2012; 23: 586-593.

19. Silva K.V., Rosa M.L., Jorge A.J. i wsp. Prevalence of risk for obstructive sleep apnea syndrome and association with risk factors in primary care. Arq. Bras. Cardiol. 2016; pii: S0066-782X2016005012102 [złożone do druku].

20. García-Díaz E., Quintana-Gallego E., Ruiz A. Respiratory polygraphy with actigraphy in the diagnosis of sleep apnea-hypopnea syndrome. Chest 2007; 131: 725-732.
21. Collop N.A., Tracy S.L., Kapur V. i wsp. Obstructive sleep apnea devices for Out-Of-Center (OOC) testing: technology evaluation. J. Clin. Sleep Med. 2011; 7: 531-548.

22. Collop N.A., Anderson W.M., Boehlecke B. i wsp. Clinical guidelines for the use of unattended portable monitors in the diagnosis of obstructive sleep apnea in adult patients. J. Clin. Sleep Med. 2007; 3: 737-747.

23. Kasai T., Floras J.S., Bradley T.D. Sleep apnea and cardiovascular disease: a bidirectional relationship. Circulation 2012; 126: 1495-1510.

24. Young T., Finn L., Peppard P.E. i wsp. Sleep disordered breathing and mortality: eighteen-year follow-up of the Wisconsin sleep cohort. Sleep 2008; 31: 1071-1078.

25. Marin J.M., Agusti A., Villar I. i wsp. Association between treated and untreated obstructive sleep apnea and risk of hypertension. JAMA 2012; 307: 2169-2176.

26. Pedrosa R.P., Drager L.F., Gonzaga C.C. i wsp. Obstructive sleep apnea: the most common secondary cause of hypertension associated with resistant hypertension. Hypertension 2011; 58: 811-817.

27. Parati G., Lombardi C., Hedner J. i wsp. Position paper on the management of patients with obstructive sleep apnea and hypertension: joint recommendations by the European Society of Hypertension, by the European Respiratory Society and by the members of European COST (COoperation in Scientific and Technological research) ACTION B26 on obstructive sleep apnea. J. Hypertens. 2012; 30: 633-646.

28. Mehra R., Benjamin E.J., Shahar E. i wsp. Association of nocturnal arrhythmias with sleep-disordered breathing: the Sleep Heart Health Study. Am. J. Respir. Crit. Care Med. 2006; 173: 910-916.

29. Gami A.S., Hodge D.O., Herges R.M. i wsp. Obstructive sleep apnea, obesity, and the risk of incident atrial fibrillation. J. Am. Coll. Cardiol. 2007; 49: 565-571.

30. Tanigawa T., Yamagishi K., Sakurai S. i wsp. Arterial oxygen desaturation during sleep and atrial fibrillation. Heart 2006; 92: 1854-1855.

31. Kent B.D., Garvey J.F., Ryan S. i wsp. Severity of obstructive sleep apnoea predicts coronary artery plaque burden: a coronary computed tomographic angiography study. Eur. Respir. J. 2013; 42: 1263-1270.

32. Mooe T., Rabben T., Wiklund U. i wsp. Sleep-disordered breathing in men with coronary artery disease. Chest 1996; 109: 659-663.

33. Peker Y., Carlson J., Hedner J. Increased incidence of coronary artery disease in sleep apnoea: a long-term follow-up. Eur. Respir. J. 2006; 28: 596-602.

34. Bradley T.D., Floras J.S. Sleep apnea and congestive heart failure: Part I: obstructive sleep apnea. Circulation 2003; 107: 1671-1678.

35. Bitter T., Westerheide N., Prinz C. i wsp. Cheyne-Stokes respiration and obstructive sleep apnoea are independent risk factors for malignant ventricular arrhythmias requiring appropriate cardioverter-defibrillator therapies in patients with congestive heart failure. Eur. Heart J. 2011; 32: $61-74$.

36. Yaggi H.K., Concato J., Kernan W.N. i wsp. Obstructive sleep apnea as a risk factor for stroke and death. N. Engl. J. Med. 2005; 353 2034-2041.

37. Sahlin C., Sandberg 0., Gustafson Y. i wsp. Obstructive sleep apnea is a risk factor for death in patients with stroke: a 10-year follow-up. Arch. Intern. Med. 2008; 168: 297-301.

38. Bozic J., Galic T., Supe-Domic D. Morning cortisol levels and glucose metabolism parameters in moderate and severe obstructive sleep apnea patients. Endocrine 2016 Mar 21 [złożone do druku]. 
39. Wozniak D.R., Lasserson T.J., Smith I. Educational, supportive and behavioural interventions to improve usage of continuous positive airway pressure machines in adults with obstructive sleep apnoea. Cochrane Database Syst. Rev. 2014; 1: CD007736.

40. Spicuzza L., Caruso D., Di Maria G. Obstructive sleep apnoea syndrome and its management. Ther. Adv. Chronic Dis. 2015; 6: 273-285.

41. Gay P., Weaver T., Loube D. Evaluation of positive airway pressure treatment for sleep related breathing disorders in adults. Sleep 2006; 29: 381-401.

42. Morgenthaler T.I., Aurora R.N., Brown T. Practice parameters for the use of autotitrating continuous positive airway pressure devices for titrating pressures and treating adult patients with obstructive sleep apnea syndrome: an update for 2007. An American Academy of Sleep Medicine report. Sleep 2008; 31: 141-147.

43. Stasche N. Selective indication for positive airway pressure (PAP) in sleep-related breathing disorders with obstruction. GMS Curr. Top. Otorhinolaryngol. Head Neck Surg. 2006; 5: Doc06.

44. Patel S.R., White D.P., Malhotra A. Continuous positive airway pressure therapy for treating sleepiness in a diverse population with obstructive sleep apnea: results of a meta-analysis. Arch. Intern. Med. 2003; 163 : 565-571.

45. Robinson G.V., Smith D.M., Langford B.A. i wsp. Continuous positive airway pressure does not reduce blood pressure in nonsleepy hypertensive OSA patients. Eur. Respir. J. 2006; 27: 1229-1235.

46. Barbé F., Duran-Cantolla J., Capote F. Long-term effect of continuous positive airway pressure in hypertensive patients with sleep apnea. Am. J. Respir. Crit. Care Med. 2010; 181: 718-726.

47. Alajmi M., Mulgrew A.T., Fox J. Impact of continuous positive airway pressure therapy on blood pressure in patients with obstructive sleep apnea hypopnea: a meta-analysis of randomized controlled trials. Lung 2007; 185: 67-72.

48. Lozano L., Tovar J.L., Sampol G. Continuous positive airway pressure treatment in sleep apnea patients with resistant hypertension: a randomized, controlled trial. J. Hypertens. 2010; 28: 2161-2168.

49. Holmqvist F., Guan N., Zhu Z. Impact of obstructive sleep apnea and continuous positive airway pressure therapy on outcomes in patients with atrial fibrillation-Results from the Outcomes Registry for Better Informed Treatment of Atrial Fibrillation (ORBIT-AF). Am. Heart J. 2015; 169: 647-654.

50. Kanagala R., Murali N.S., Friedman P.A. i wsp. Obstructive sleep apnea and the recurrence of atrial fibrillation. Circulation 2003; 107 : 2589-2594.

51. Naruse Y., Tada H., Satoh M. i wsp. Concomitant obstructive sleep apnea increases the recurrence of atrial fibrillation following radiofrequency catheter ablation of atrial fibrillation: clinical impact of continuous positive airway pressure therapy. Heart Rhythm 2013; 10: 331-337.

52. Kaneko Y., Floras J.S., Usui K. Cardiovascular effects of continuous positive airway pressure in patients with heart failure and obstructive sleep apnea. N. Engl. J. Med. 2003; 348: 1233-1241.
53. Kasai T., Narui K., Dohi T. Prognosis of patients with heart failure and obstructive sleep apnea treated with continuous positive airway pressure. Chest 2008; 133: 690-696.

54. Bitter T., Gutleben K.J., Nölker G. i wsp. Treatment of Cheyne-Stokes respiration reduces arrhythmic events in chronic heart failure. J. Cardiovasc. Electrophysiol. 2013; 24: 1132-1140.

55. Salord N., Fortuna A.M., Monasterio C. i wsp. a randomized controlled trial of continuous positive airway pressure on glucose tolerance in obese patients with obstructive sleep apnea. Sleep 2016; 39: 35-41.

56. Martínez-Ceron E., Fernández-Navarro I., Garcia-Rio F. Effects of continuous positive airway pressure treatment on glucose metabolism in patients with obstructive sleep apnea. Sleep Med. Rev. 2016; 25: 121-130.

57. Scherr S.C., Dort L.C., Almeida F.R. i wsp. Definition of an effective oral appliance for the treatment of obstructive sleep apnea and snoring: a report of the American Academy of Dental Sleep Medicine. J. Dent. Sleep Med. 2014; 1: 39-50.

58. Ramar K., Dort L.C., Katz S.G. i wsp. Clinical practice guideline for the treatment of obstructive sleep apnea and snoring with oral appliance therapy: an update for 2015: an American Academy of Sleep Medicine and American Academy of Dental Sleep Medicine clinical practice guideline. J. Clin. Sleep Med. 2015; 11: 773-827.

59. Korczynski P. Oral appliances for patients with OSAS. Pneumonol. Alergol. Pol. 2007; 75 (supl. 1): 35-38.

60. Van Haesendonck G., Dieltjens M., Hamans E. i wsp. Treatment efficacy of a titratable oral appliance in obstructive sleep apnea patients: a prospective clinical trial. B-ENT 2016; 12: 1-8.

61. Cilil V.R., Sapana Varma N.K., Gopinath S., Ajith V.V. Efficacy of custom made oral appliance for treatment of obstructive sleep apnea. Contemp. Clin. Dent. 2015; 6: 341-347.

62. Sutherland K., Vanderveken O.M., Tsuda H. i wsp. Oral appliance treatment for obstructive sleep apnea: an update. J. Clin. Sleep Med. 2014; 10: 215-227.

63. Marklund M. Long-term efficacy of an oral appliance in early treated patients with obstructive sleep apnea. Sleep Breath 2016; 20 : 689-694.

64. Mehta A., Qian J., Petocz P. i wsp. A randomized, controlled study of a mandibular advancement splint for obstructive sleep apnea. Am. J. Respir. Crit. Care Med. 2001; 163: 1457-1461.

65. Ashrafian H., Toma T., Rowland S.P. Bariatric surgery or non-surgical weight loss for obstructive sleep apnoea? A systematic review and comparison of meta-analyses. Obes. Surg. 2015; 25 : 1239-1250.

66. Frank M.H., Ravesloot M.J., van Maanen J.P. Positional OSA part 1: towards a clinical classification system for position-dependent obstructive sleep apnoea. Sleep Breath. 2015; 19: 473-480.

67. Bidarian-Moniri A., Nilsson M., Rasmusson L. The effect of the prone sleeping position on obstructive sleep apnoea. Acta Otolaryngol. 2015; 135: 79-84. 